\title{
PENGEMBANGAN MULTIMEDIA INTERAKTIF UNTUK PEMBELAJARAN MENULIS TEKS CERPEN
}

\author{
Anisa Ulfah (Corresponding Author) \\ PBSI Universitas Islam Darul Ulum Lamongan \\ J1. Airlangga 03, Sukodadi, Lamongan, Kabupaten Lamongan, Indonesia \\ Phone: 081252695936 E-mail: anisaulfah.pbi@gmail.com
}

\begin{abstract}
ABSTRAK: Pengembangan ini bertujuan untuk menghasilkan multimedia interaktif untuk pembelajaran menulis teks cerpen serta mendeskripsikan tingkat kelayakan media. Pengembangan dilakukan dengan model pengembangan prosedural yang meliputi tahap prapengembangan, pengembangan, validasi, dan revisi. Produk dikembangkan berdasarkan tiga aspek, yaitu isi media, tampilan media, dan bahasa. Validasi dilakukan kepada ahli materi dan ahli media. Hasil validasi menunjukkan bahwa produk telah layak dan dapat diimplementasikan dalam pembelajaran menulis cerpen di sekolah.
\end{abstract}

Kata Kunci: media pembelajaran, menulis teks cerpen, multimedia interaktif

Perkembangan teknologi pembelajaran, yaitu sebagai alat untuk memberikan manfaat bagi kehidupan memperjelas bahan pengajaran, serta masyarakat di semua bidang, termasuk sebagai sumber belajar bagi siswa, di bidang pendidikan. Perkembangan artinya media tersebut berisikan bahanteknologi yang semakin pesat tersebut bahan yang harus dipelajari siswa, baik dapat dimanfaatkan untuk secara individual atau kelompok pengembangan media pembelajaran. (Sudjana dan Rivai, 2010:6). Dengan Tujuannya adalah untuk menciptakan pembelajaran yang aktif dan menyenangkan dengan cara menghadirkan media pembelajaran. Kehadiran media pembelajaran memiliki demikian, kehadiran media dalam proses pembelajaran dapat membantu kesulitan siswa dalam belajar sehingga tujuan pembelajaran dapat dicapai siswa secara optimal.

peran penting dalam proses 
Ada berbagai jenis media pembelajaran yang dapat membantu meningkatkan motivasi belajar siswa, salah satunya adalah media interaktif. Ariani dan Haryanto (2010:25) menjelaskan bahwa multimedia interaktif adalah media pembelajaran yang dilengkapi dengan alat pengontrol yang dapat dioperasikan secara mandiri. Adanya alat pengontrol tersebut dapat memberikan kesempatan kepada siswa untuk dapat menentukan sendiri alur belajarnya. Penggunaan media berbasis multimedia interaktif dapat memberikan kesempatan pada siswa untuk berinteraksi secara langsung dengan media. Oleh sebab itu, pengembangan media pembelajaran berbasis multimedia interaktif ini diharapkan dapat memudahkan siswa karena mereka dapat menentukan kecepatan belajarnya secara mandiri.

Adanya media dalam pembelajaran tidak hanya menggantikan guru untuk menyajikan materi, tetapi media merupakan alat penyalur pesan atau informasi yang dibutuhkan dalam pembelajaran. Unsur gambar (visual) dan unsur suara (audio) yang disusun secara menarik dan mudah dipahami akan membuat pengguna media tertarik untuk memperoleh informasi yang ada di dalamnya (Pribadi dan Katrin, 2004:5). Dengan demikian, media dapat menyampaikan pesan yang sebelumnya dianggap sulit untuk disampaikan secara menarik dan tidak membosankan apabila dikembangkan dengan penuh kreativitas. Berdasarkan studi pendahuluan di beberapa sekolah, media yang digunakan guru dalam pembelajaran menulis teks cerpen adalah lembaran kertas berisi teks cerpen yang kemudian dibaca siswa sebagai contoh. Di samping itu, guru juga mengandalkan buku teks pelajaran atau lembar kerja siswa (LKS) sebagai penunjang. Buku teks atau LKS memberikan informasi yang terbatas, sedangkan pembelajaran menulis cerpen memerlukan bahan atau media lain agar pembelajaran menulis teks cerpen dapat disajikan secara optimal. Multimedia interaktif dianggap dapat menjawab permasalahan tersebut karena pembelajaran berbasis multimedia interaktif akan memberikan pengalaman belajar yang bermakna pada siswa. Adapun karakteristik pembelajaran berbasis multimedia adalah (1) pembelajaran disampaikan melalui media elektronik, (2) adanya respons pembelajaran dan penguatan, dan (3) 
mengembangkan prinsip penilaian mandiri (Darmawan, 2011:32).

Pengembangan media pembelajaran menulis teks cerpen berbasis multimedia interaktif ini diharapkan bisa menjadi inovasi baru dalam pembelajaran menulis cerpen. Cerpen adalah karya sastra berbentuk prosa yang memiliki alur cerita lebih sederhana dibandingkan novel. Siswanto (2008:24) menyatakan bahwa menulis cerpen merupakan proses kreatif yang meliputi lima tahapan, yaitu mendapatkan ide, merenungkannya, menyusun kata-kata, memperbaikinya, sampai kalau perlu mengirimkannya ke media massa.

Landasan pembelajaran dalam media ini adalah kontruktivistik. Kontruktivistik merupakan teori yang berasal dari disiplin filsafat. Kontruktivistik mendapat pengaruh dari disiplin psikologi kognitif Peaget yang berkaitan dengan mekanisme psikologi yang mendorong terbentuknya pengetahuan personal dan psikologi sosial. Vygotsky yang mengarah pada keterampilan sosial untuk belajar bersama teman, guru, dan para ahli. Kedua perspektif tersebut sama-sama mengimplikasikan pentingnya keaktifan siswa dalam belajar. Keduanya menekankan tindakan terhadap objek, bedanya Peaget menekankan pentingnya keaktifan individu dalam melakukan tindakan terhadap objek, sedangkan Vygotsky menekankan pentingnya lingkungan sosio-kultural dalam melakukan tindakan terhadap objek.

Suprijono (2011:30) menyatakan dalam kontruktivistik pengetahuan dipandang sebagai factum (apa yang diketahui), et verum (apa yang diketahui), dan convertuntur (konvertibel antara satu terhadap lainnya). Dengan demikian pengetahuan dikonstruksi berdasarkan pengalaman sendiri sehingga cenderung subjektif. Dalam teori kontruktivistik belajar dipahami sebagai proses aktif, siswalah yang aktif mengkontruksi pengetahuan (Soeparno, 1997:97). Sehubungan dengan hal tersebut, Priyatni (2014:40) menyimpulkan bahwa kontruktivistik mengarahkan belajar adalah proses mengontruksi pengetahuan dengan cara mengabstraksi pengalaman sebagai hasil interaksi antara siswa dengan realitas baik realitas pribadi, alam, maupun realitas sosial yang bersifat aktif dan dinamis. Dengan kata lain, faktor yang mempengaruhi kontruksi pengetahuan 
siswa antara lain pengalaman, pengetahuan awal, kemampuan kognitif, dan lingkungan. Dengan demikian, konstruksi pengetahuan tidak berangkat dari "pikiran kosong", siswa harus memiliki pengetahuan apa yang hendak diketahui. Dalam proses mengonstruksi pengetahuan, siswa melakukan analisis, sintesis, argumentasi, pengambilan keputusan, dan penarikan kesimpulan sekalipun bersifat tentatif.

Media pembelajaran ini mengarahkan siswa kepada kegiatan menulis cerpen. Sesuai dengan landasan kontruktivistik, media ini diawali dengan latihan-latihan dan diakhiri dengan penyimpulan latihan tersebut. Adapun teori pembelajaran dalam media ini yakni pemodelan, mengubah, dan mengkreasi berdasarkan unsur intrinsik cerpen. Sesuai dengan pendapat Siswanto (2014:11) langkah dasar menulis cerpen adalah menentukan tema, sedangkan langkah terakhir adalah mengakhiri cerita. Berdasarkan uraian tersebut, media pembelajaran ini diawali dengan pemodelan cerpen, menentukan unsur intrinsik, mengubah unsur intrinsik, dan mengkreasikan unsur intrinsik cerpen. Media ini juga dilengkapi evaluasi pembelajaran menulis cerpen. Hingga akhirnya siswa menghasilkan cerpen baru. Dengan demikian, media yang dikembangkan dapat dikatakan telah sesuai dengan kontruktivistik.

Multimedia interaktif yang dikembangkan dalam penelitian ini menggunakan aplikasi Lectora Inpire. Aplikasi Lectora Inpire merupakan aplikasi yang digunakan untuk presentasi maupun multimedia pembelajaran. Aplikasi ini dapat dikatakan mudah dioperasikan karena tidak memerlukan pemahaman bahasa pemrograman. Aplikasi ini digunakan untuk menggabungkan teks, gambar, flash, audio, dan video. Menurut Mas'ud (2012:3), aplikasi ini memiliki kelebihan antara lain (1) dapat digunakan membuat website, e-learning interaktif, presentasi produk, (2) fitur yang disediakan mudah dipahami, (3) bagi guru memudahkan pembelajaran, (4) menyediakan Library yang membantu pengguna, dan (5) mampu mengonversi Ms. Word dan Ms. Excel.

Penelitian pengembangan media pembelajaran sudah pernah dilakukan, salah satunya oleh Nasinha (2012) yang mengembangkan media pembelajaran menulis puisi. Penelitian tersebut 
dilakukan dengan judul Pengembangan Media Pembelajaran Menulis Puisi Berbasis Tayangan Acara Televisi untuk Siswa Kelas VIII. Tujuan penelitian ini adalah untuk mengembangkan isi media serta untuk mengetahui tingkat kemanfaatan serta kemenarikan media pembelajaran yang dihasilkan. Penelitian pengembangan juga dilakukan oleh Kuswidarti (2013) dengan judul Pengembangan Media Permainan Monopoli "Apresiator" untuk Meningkatkan Kemampuan Apresiasi Cerpen Siswa SMA. Penelitian tersebut menyatakan bahwa media tersebut layak dan menarik untuk digunakan dalam pembelajaran apresiasi cerpen. Siswa memberi respons positif bahwa dengan belajar menggunakan media monopoli "Apresiator" siswa dapat mengapresiasi cerpen secara lebih mendalam dan menyenangkan. Penelitian-penelitian tersebut berbeda dengan penelitian ini karena kompetensi yang dikembangkan penelitian ini adalah menulis teks cerpen. Penyajian pembelajaran yang digunakan dalam media ini juga telah mengadaptasi metode pembelajaran Kurikulum 2013, yaitu metode saintifik. Sesuai dengan metode saintifik, penyajian materi pembelajaran dalam media ini diawali dengan kegiatan mengamati, menanya, mencoba, dan menalar yang diimplementasikan secara implisit dalam media.

Berdasarkan uraian tersebut, tujuan umum penelitian ini ialah menghasilkan produk multimedia interaktif dalam pembelajaran menulis teks cerpen. Adapun tujuan penelitian secara khusus, yaitu (1) mengembangkan isi, bahasa, dan tampilan multimedia interaktif dalam pembelajaran menulis teks cerpen dan (2) mendeskripsikan tingkat kelayakan media yang dihasilkan. Media dikembangkan berdasarkan tiga aspek, yaitu aspek isi, tampilan, dan bahasa media. Media yang dihasilkan ditujukan untuk siswa menengah atas (SMA) sederajat.

\section{METODE}

Penelitian ini menggunakan
desain penelitian pengembangan. Adapun model pengembangan penelitian ini adalah model prosedural yang mengadaptasi model Borg dan Gall (1983:775). Prosedur penelitian ini meliputi empat tahap, yaitu (1) tahap prapengembangan, (2) tahap pengembangan, (3) validasi, dan (4) tahap revisi. Kegiatan yang dilakukan 
pada tahap prapengembangan adalah studi pendahuluan dengan cara melakukan studi pustaka, telaah media yang telah ada, wawancara, diskusi, dan mengumpulkan bahan-bahan yang diperlukan dalam tahap pengembangan. Kegiatan yang dilakukan dalam tahap selanjutnya ialah mengembangkan desain produk media pembelajaran. Tahap validasi dilakukan dengan ahli materi dan media. Produk tidak diujicobakan karena keterbatasan waktu. Uji ahli dilakukan seminggu sekali dengan cara konsultasi dan diskusi selama empat bulan. Kemudian tahap terakhir adalah melakukan revisi sesuai dengan masukan dan saran perbaikan yang diperoleh dari kegiatan uji ahli tersebut.

Desain validitas produk dalam pengembangan ini menggunakan desain deskripstif. Desain deskriptif dipilih karena data yang diperoleh dari uji ahli yang telah dilakukan digambarkan secara objektif, baik mengenai kekurangan maupun kelebihan produk. Hal ini dilakukan agar dapat diperoleh data secara lengkap sebagai bahan untuk perbaikan produk. Produk diujiahlikan kepada kedua dosen yang ahli dalam media menulis cerpen yang telah berpengalaman dalam pembelajaran sastra serta dunia media pembelajaran.

Instrumen pengumpulan data penelitian ini dibedakan menjadi dua, yaitu instrumen prapengembangan dan instrumen uji ahli. Instrumen yang digunakan pada tahap prapengembangan adalah pedoman wawancara. Wawancara dilakukan untuk mengumpulkan informasi tentang ketersediaan media dan kebutuhan media pembelajaran yang sesuai dengan karakteristik siswa. Jenis wawancara yang digunakan dalam pengembangan media pembelajaran ini adalah wawancara semiformal. Adapun instrumen uji ahli adalah lembar diskusi. Lembar tersebut berisi uraian tiga aspek yang didiskusikan dalam media pembelajaran menulis teks cerpen, yaitu (1) isi media pembelajaran, (2) bahasa media pembelajaran, dan (3) tampilan media pembelajaran.

Jenis data dalam penelitian ini adalah data verbal. Data verbal diperoleh dari tahap prapengembangan dan uji ahli. Data verbal adalah data hasil transkrip wawancara pada tahap prapengembangan dan data hasil catatan, komentar, serta saran perbaikan yang diperoleh dari para ahli dan kelompok kecil saat dilakukan uji validasi. 


\section{HASIL}

\section{Deskripsi Produk Awal.}

Pengembangan ini menghasilkan produk media pembelajaran berupa multimedia interaktif pembelajaran menulis teks cerpen yang dikemas dalam Compact Disk (CD). Media pembelajaran diberi nama Ayo, Berlatih Menulis Cerpen!. Secara umum isi media pembelajaran ini terdiri atas enam menu utama. Keenam menu tersebut yaitu kompetensi, materi, latihan, evaluasi, sumber belajar, dan profil pengembang. Menu kompetensi berisi informasi tujuan pembelajaran yang harus dicapai siswa. Menu materi menyajikan bahan ajar yang dijadikan sebagai bekal bagi siswa dalam materi menguasai kompetensi pembelajaran menulis teks cerpen. Menu latihan berisi latihan-latihan yang harus dikerjakan siswa sebagai tahap sebelum siswa menulis cerpen secara utuh. Menu evaluasi berisi tugas-tugas yang harus dikerjakan siswa sebagai indikator pencapaian kompetensi siswa. Menu sumber belajar menyajikan bacaan berupa contoh-contoh teks cerpen. Menu profil pengembang berisi informasi dan identitas pengembang media.
Menu materi pembelajaran berisi submenu teks cerpen, tema, amanat, alur, tokoh dan watak, latar, sudut pandang, kerangka cerita, mengembangkan cerita, dan menyunting. Setiap submenu diawali dengan pertanyaan-pertanyaan yang berasal dari cerpen yang telah dibaca siswa. Kemudian siswa diberi pertanyaan yang merupakan pertanyaan untuk mengarahkan siswa menyimpulkan submateri yang dibahas. Menu latihan memberikan latihan kepada siswa secara bertahap dalam menulis cerpen. Latihan dikerjakan dengan cara disajikan kutipan cerpen kemudian siswa mengerjakan latihannya sesuai dengan aspek yang sedang dilatihkan. Menu evaluasi menyajikan cerpen baru yang digunakan sebagai bahan dalam menulis cerpen baru. Sumber belajar dapat digunakan siswa sebagai bahan atau inspirasi dalam menulis cerpen.

Keunggulan media yang dihasilkan ialah pembelajaran disajikan sesuai dengan model pembelajaran konstrutivistik. Selain itu, media pembelajaran juga memiliki tampilan yang menarik sehingga dapat menumbuhkan motivasi belajar siswa. Kemenarikan tersebut terlihat pada 
pengorganisasian isi media, penyajian komposisi warna-warna yang harmonis, serta konsistensi dalam penggunaan tombol-tombol interaktif. Media pembelajaran ini juga menggunakan bahasa yang komunikatif dan interaktif sehingga akan mudah dipahami dan siswa dapat berinteraksi langsung dengan media. Penggunaan tomboltombol interaktif yang konsisten juga dapat memudahkan siswa dalam mengoperasikan media. Media juga diiringi dengan instrumen musik yang dapat membuat suasana belajar menjadi santai dan menyenangkan.

\section{Hasil Validasi Ahli}

Validasi dilakukan kepada ahli media pembelajaran menulis cerpen dan media pembelajaran, yaitu (1) ahli materi pembelajaran menulis cerpen dan (2) ahli media pembelajaran. Fokus penilaian media pembelajaran ini ada tiga aspek utama, yaitu (1) isi media pembelajaran, (2) bahasa media pembelajaran, dan (3) tampilan media pembelajaran. Aspek isi media meliputi kelengkapan identitas media, kesistemastisan penyajian pembelajaran, kelengkapan materi pembelajaran, dan ketepatan kegiatan pembelajaran. Aspek tampilan media meliputi kemudahan tombol interaktif, keharmonisan komposisi warna, dan kesesuaian instrumen musik. Berdasarkan analisis data yang dilakukan sesuai dengan kriteria kelayakan produk yang telah ditentukan, menunjukkan bahwa media telah layak untuk diimplementasikan. Adapun aspek bahasa meliputi ketepatan pilihan kata atau nama menu, kejelasan tulisan, keformalan bahasa, dan keinteraktifan bahasa. Hasil validasi juga menunjukkan bahwa media dilihat dari aspek bahasa telah berkategori layak dan dapat diimplementasikan pada pembelajaran. Meskipun ketiga aspek media telah berkategori layak untuk diimplementasikan, media tetap direvisi sesuai dengan saran perbaikan dan masukan dari subjek coba untuk menyempurnakan produk.

\section{Revisi Produk}

Produk yang telah diujikan dapat disimpulkan bahwa produk telah layak untuk diimplementasikan, tetapi media direvisi sesuai dengan kebutuhan. Revisi dilakukan dengan tujuan untuk lebih menyempurnakan produk. Berdasarkan hasil analisis data menunjukkan bahwa aspek yang perlu direvisi berdasarkan saran yang diberikan subjek coba dibedakan menjadi tiga aspek. Aspek isi 
media memperoleh beberapa saran perbaikan, yaitu (1) membedakan halaman tujuan dan manfaat pembelajaran pada menu kompetensi, (2) menambah materi unsur intrinsik, (3) mengganti teks contoh kegiatan menulis cerpen, dan (4) menambah kegiatan latihan. Adapun aspek tampilan memperoleh beberapa masukan, yaitu memperbesar ukuran huruf pada teksteks contoh dan mengganti beberapa latar belakang dengan yang lebih menarik. Adapun aspek bahasa yang mendapat masukan adalah kejelasan perintah dan petunjuk yang diberikan media. Salah satu instrumen musik juga perlu diganti agar lebih sesuai sebagai pengiring musik belajar dan tidak mengganggu pembelajaran.

\section{Produk Akhir Dan Kajian Produk}

Pembelajaran menulis cerpen merupakan salah satu kompetensi dasar (KD) pada standar isi Kurikulum 2013 maupun kurikulum satuan tingkat pendidikan (KTSP). Dalam rangka mewujudkan pembelajaran yang aktif, menyenangkan, dan dapat menarik perhatian siswa, seorang guru dapat menggunakan media pembelajaran untuk menunjang proses pembelajaran. Media pembelajaran adalah bagian yang tidak dapat terpisahkan dari proses belajar mengajar demi tercapainya tujuan pendidikan pada umumnya dan tujuan pembelajaran di sekolah pada khususnya (Arsyad, 2009:2). Pendapat tersebut dikuatkan oleh pendapat Sudjana dan Rivai (2010:2) yang menyatakan bahwa media pembelajaran dapat mempertinggi proses belajar siswa dalam pembelajaran yang pada gilirannya diharapkan dapat mempertinggi hasil belajar yang dicapainya. Oleh karena itu, untuk mencapai tujuan pembelajaran menulis teks cerpen sesuai dengan yang diharapkan, seorang guru membutuhkan sebuah media pembelajaran yang dapat mendukung dalam proses pembelajaran.

\section{Kajian Isi Produk Media}

\section{Pembelajaran}

Media pembelajaran yang dihasilkan dalam pengembangan ini merupakan media pembelajaran berbasis multimedia interaktif. Multimedia interaktif adalah suatu multimedia yang dilengkapi dengan alat pengontrol yang dapat dioperasikan oleh pengguna sehingga pengguna dapat memilih apa yang dikehendaki untuk proses selanjutnya (Ariani dan Haryanto, 
2010:25). Hal tersebut menjadi acuan dalam pengembangan media ini. Media yang dihasilkan telah menyediakan alat pengontrol berupa tombol-tombol interaktif yang dapat melibatkan siswa dalam pembelajaran. Keterlibatan siswa secara langsung tersebut diharapkan agar siswa dapat memperoleh pemahaman yang lebih tentang bahan pembelajaran yang disajikan serta dapat berlatih menulis cerpen secara langsung.

Media pembelajaran berbasis multimedia interaktif ini juga dikembangkan dengan mempertimbangkan karakteristik pembelajaran multimedia, yaitu (1) isi tersajikan tidak dalam satu format, (2) tampilan penuh warna, (3) melalui media elektronik, (4) tipe-tipe pembelajaran yang bervariasi, (5) respons pembelajaran dan penguatan, mengembangkan prinsip penilaian diri, dan (6) dapat digunakan secara klasikal atau individual (Darmawan, 2011:117). Karakteristik-karakteristik tersebut diimplementasikan pengembangan media. Hal ini dimaksudkan agar media yang dihasilkan sesuai dengan prinsip pengembangan media pembelajaran berbasis multimedia interaktif. Media juga diharapkan dapat bermanfaat dalam proses pembelajaran menulis teks cerpen. Isi media pembelajaran yang dihasilkan dikaji sesuai dengan empat aspek indikator, meliputi identitas media pembelajaran, kesistematisan strategi pembelajaran, penyajian materi pembelajaran, dan ketepatan materi pembelajaran.

Pertama, identitas media pembelajaran meliputi kompetensi, sasaran pengguna, tujuan pembelajaran, dan manfaat pembelajaran. Keempat identitas tersebut telah disajikan dalam media. Kompetensi dan sasaran pengguna tersaji sebagai judul media yang keluar di awal setiap kali media digunakan. Adapun tujuan dan manfaat pembelajaran tersaji dalam salah satu menu utama media, yaitu menu kompetensi. Identitas media pembelajaran merupakan hal mutlak yang harus ada pada media yang dikembangkan. Hal ini dikarenakan pengembangan media pembelajaran harus berdasarkan kurikulum yang digunakan sehingga media yang dihasilkan telah memiliki keterangan identitas. Dalam merencanakan pemanfaatan media pengembang harus melihat tujuan yang akan dicapai, materi pembelajaran yang mendukung, serta 
strategi belajar mengajar yang sesuai untuk mencapai tujuan tersebut (Sadiman, 2008:182). Sesuai dengan kurikulum yang digunakan dalam pengembangan media ini sasaran pengguna media adalah siswa tingkat menengah atas atau sederajat kelas $\mathrm{X}$. Adapun masing-masing tujuan dan manfaat pembelajaran telah dicantumkan dalam media. Dengan demikian, identitas media yang setidaknya meliputi empat keterangan tersebut harus dicantumkan dalam media. Berikut ini gambar yang menunjukkan menu kompetensi.

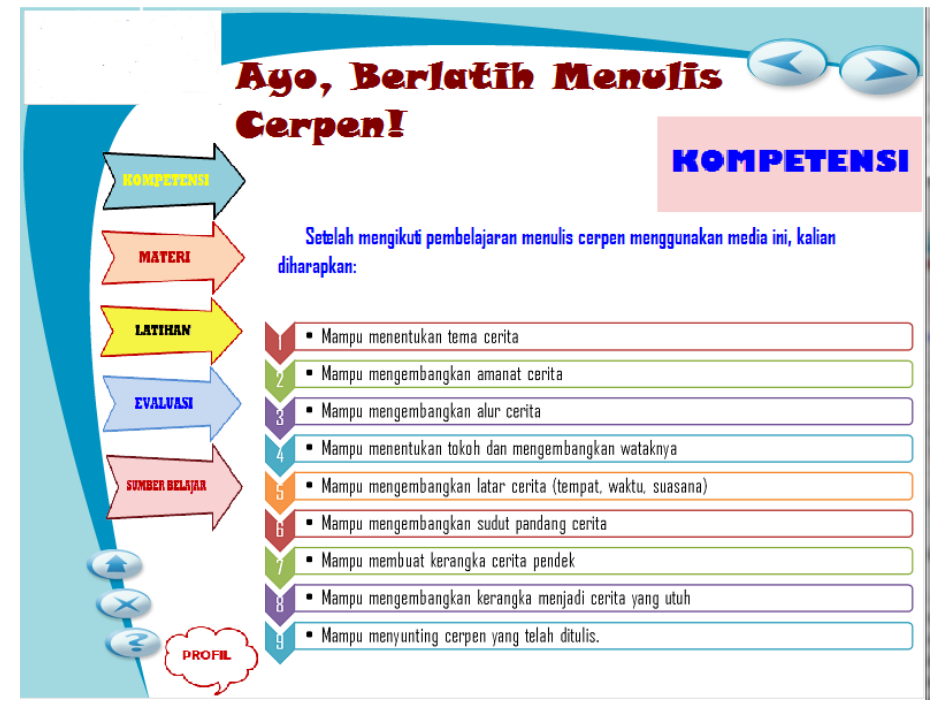

Gambar 1 Isi dan Tampilan Menu Kompetensi

Kedua, kesistematisan strategi pembelajaran. Berdasarkan hasil analisis data yang telah dilakukan, strategi pembelajaran yang direncanakan mendapat kriteria layak sehingga strategi yang mengadaptasi dari metode saintifik tersebut dapat diterapkan dalam pembelajaran. Strategi pembelajaran merupakan rencana tindakan (rangkaian kegiatan) termasuk penggunaan metode dan pemanfaatan berbagai sumber daya dalam pembelajaran yang disusun untuk mencapai tujuan pembelajaran (Arifin dan Setiyawan, 2012:56). Strategi yang digunakan dalam pengembangan media ini meliputi empat tahap, yaitu mengamati, menanya, menalar, dan mencoba. Namun, sebagai penguatan karakter siswa ada dua tahap lagi yang dilakukan siswa, yaitu kegiatan berdoa 
ISSN : 23557083

Volume 4 Nomor 1 Juni 2017

sebelum memulai pembelajaran dan kegiatan latihan sebagai wujud strategi kegiatan refleksi yang dilakukan setelah pembelajaran yang digunakan dalam kegiatan pembelajaran selesai. Berikut media. ini gambar yang menunjukkan menu

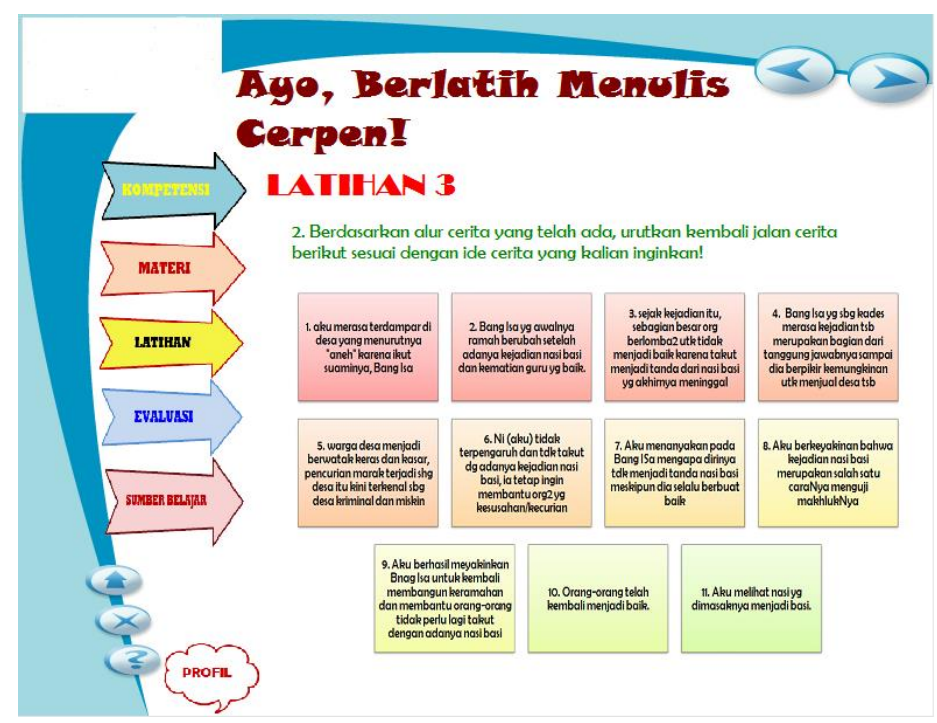

Gambar 2 Isi dan Tampilan Menu Latihan

Ketiga, penyajian materi pembelajaran. Media menyajikan semua aspek materi pembelajaran sesuai dengan kompetensi pembelajaran, yaitu menulis teks cerpen. Materi terkait kompetensi tersebut meliputi (1) tema, (2) amanat, (3) alur, (4) latar, (5) tokoh dan watak, (6) sudut pandang, (7) membuat kerangka, mengembangkan kerangka menjadi tulisan utuh, dan (9) menyunting. Materi tersebut disajikan secara berurutan, tetapi siswa juga diberi kesempatan untuk menentukan sendiri materi yang ingin dipelajarinya. Berikut ini gambar yang menunjukkan pilihan submenu materi. 
ISSN : 23557083

Volume 4 Nomor 1 Juni 2017

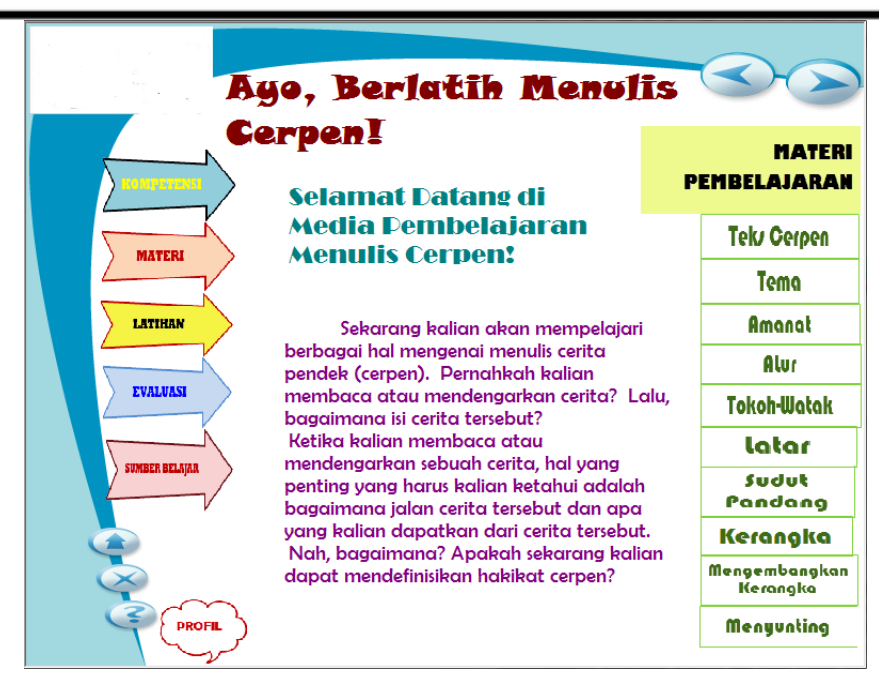

Gambar 3 Isi dan Tampilan Menu Materi

Keempat, ketepatan materi pembelajaran. Kelayakan materi pembelajaran. Berdasarkan analisis data pelajaran tersebut ditunjukkan dengan hasil uji coba yang dilakukan, materi tidak ditemukannya kesalahan konsep pembelajaran telah direvisi sesuai dengan masukan yang diberikan oleh para ahli sehingga materi yang disajikan dan teori dalam penyajian materi. Berikut ini gambar yang menunjukkan salah satu materi pembelajaran.

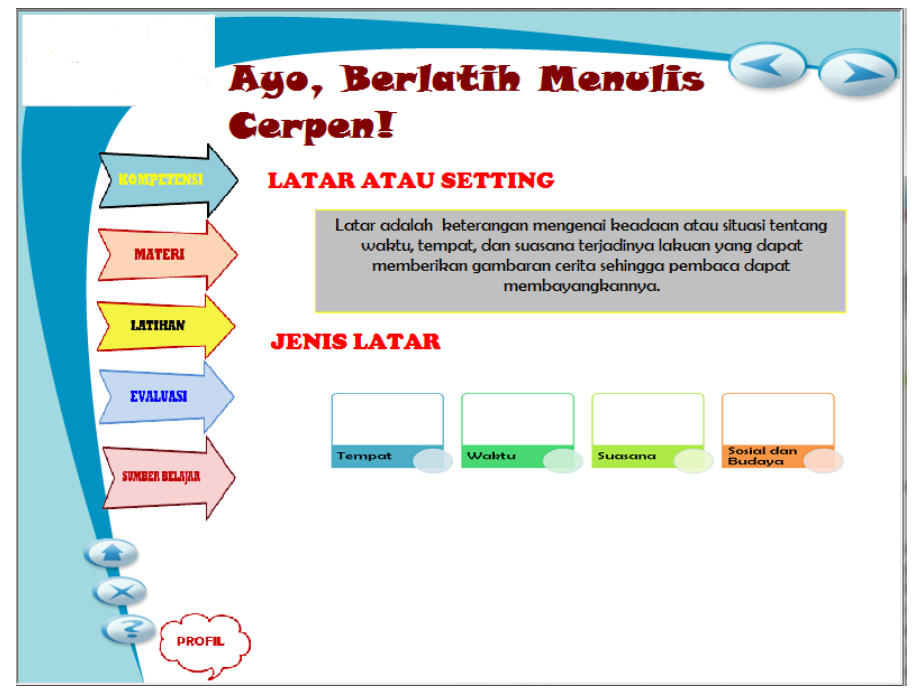

Gambar 4 Isi dan Tampilan Submenu Materi 
Kajian Produk Tampilan Media

\section{Pembelajaran}

Tampilan media pembelajaran yang dihasilkan dikaji sesuai dengan tiga aspek, meliputi penggunaan tombol-tombol interaktif, komposisi warna yang harmonis, dan instrumen musik. Pertama, penggunaan tomboltombol interaktif dalam media. Media yang dihasilkan dalam pengembangan ini adalah berbasis multimedia interaktif sehingga penggunaan tombol-tombol interaktif sudah pasti harus ada dalam media. Multimedia interaktif adalah suatu multimedia yang dilengkapi dengan alat pengontrol yang dapat dioperasikan oleh pengguna sehingga pengguna dapat memilih apa yang dikehendaki untuk proses selanjutnya (Ariani dan Haryanto, 2010:25). Alat pengontrol yang dimaksud tersebut adalah tombol-tombol interaktif. Jadi, media pembelajaran harus memiliki tombol interaktif yang membuat siswa beriteraksi dengan media secara langsung. Penggunaan tombol interaktif media pembelajaran ini didominasi dengan bentuk panah agar mudah dipahami siswa. Kegunaan masingmasing tombol interaktif tersebut juga telah dijelaskan secara detail pada menu petunjuk penggunaan. Jenis tombol interaktif tersebut juga tidak banyak karena mempertimbangkan aspek kemudahan pengoperasian media. Tombol interaktif digunakan secara konsisten dan berada pada pojok kanan atas. Ada pula beberapa yang diletakkan pada ruang kosong sehingga tombol tersebut lebih terlihat.

Kedua, keharmonisan komposisi warna-warna yang ditampilkan. Tampilan yang tampak dalam media juga berpengaruh motivasi siswa dalam belajar sehingga tampilan media harus terlihat menarik. Tampilan unsur tata letak, elemen warna, dan ilustrasi harus ditampilkan secara harmonis dan saling terkait satu dengan lainnya (Muslich, 2010:306). Oleh sebab itu, keharmonisan komposisi warna media akan menampilkan media menulis teks cerpen yang nyaman dan menyenangkan. Komposisi warna yang digunakan dalam media adalah kombinasi warna-warna pastel. Warna ini dipilih agar tampilan media menarik karena dalam media terdapat banyak tulisan sehingga jika menggunakan warna-warna terang yang mencolok dapat mengganggu saat membaca tulisan. 
Ketiga, instrumen musik yang mengiringi media pembelajaran. Instrumen musik telah diganti sesuai dengan masukan dari para subjek coba karena sebelumnya instrumen musik dinilai menggannggu. Oleh sebab itu instrumen musik diganti dengan yang lebih sesuai untuk mengiringi pembelajaran. Selain itu, adanya instrumen musik juga diharapkan dapat memotivasi siswa dalam belajar. Visual, musik, dan efek suara yang relevan dengan materi akan menjaga pengguna media untuk terus tertarik menggunakan media (Ariani dan Haryanto, 2010:107). Instrumen musik ini dapat diatur secara manual oleh siswa jika tidak ingin menggunakan iringan musik dalam penggunaan media.

\section{Kajian Bahasa Media Pembelajaran}

Bahasa media pembelajaran yang dihasilkan dikaji sesuai dengan tiga aspek, meliputi ketepatan pilihan kata dan penyusunan kalimat, kemudahan memahami bahasa, dan keinteraktifan bahasa. Pertama, beberapa kalimat yang digunakan masih menggunakan kalimat yang panjang sehingga direvisi menjadi kalimatkalimat efektif agar mudah dipahami.
Sadiman (2008:114) mengatakan bahwa bahasa pada media sedapat mungkin menggunakan kalimat tunggal karena kalimat yang panjang sulit ditangkap oleh pengguna. Selain itu, pilihan kata yang digunakan untuk memberikan nama dan jenis kegiatan yang dipilih telah tepat. Hal ini berdasarkan hasil uji coba yang dilakukan tidak ditemukan komentar dan saran untuk mengubah atau mengganti nama-nama menu dan submenu pada media.

Kedua, kemudahan dalam memahami bahasa juga menjadi pertimbangan. Pemakaian bahasa yang mengikuti kaidah yang dilakukan atau yang dianggap baku melahirkan bahasa yang benar. Pemanfaatan ragam yang tepat dan serasi menurut golongan penutur dan jenis pemakaian bahasa disebut bahasa yang baik atau tepat (Muslich, 2010:9). Pernyataan tersebut merupakan dasar dalam pemilihan ragam bahasa yang digunakan media. Meskipun dalam situasi pembelajaran yang seharusnya menggunakan bahasa formal, tetapi bahasa yang digunakan tetap komunikatif. Bahasa ini dipilih agar situasi pembelajaran yang terbangun tidak terasa kaku. Semua perintah, petunjuk, dan keterangan yang 
diberikan diungkapkan dengan bahasa yang jelas agar tidak membingungkan.

Ketiga, penggunaan bahasa mengajak siswa untuk beriteraksi. Mbulu dan Suhartono (2004:105) mengatakan bahwa bahasa yang digunakan dalam bahan atau media pembelajaran bukanlah bahasa formal, melainkan bahasa yang setengah formal dan setengah lisan. Oleh sebab itu, bahasa yang digunakan dalam media dibuat seinteraktif mungkin agar tidak terkesan kaku dan formal. Bahasa yang interaktif tersebut diindikatori oleh penggunaan kata sapaan secara konsisten. Sapaan yang digunakan dalam media untuk menyapa siswa adalah kalian. Bahasa yang digunakan untuk berinteraksi dalam setiap kegiatan yang dilakukan oleh siswa juga menggunakan bahasa yang komunikatif. Hal ini mempertimbangkan aspek psikologis siswa sehingga siswa tidak merasa tertekan dan merasa nyaman belajar dengan media pembelajaran yang dihasilkan.

\section{PENUTUP}

\section{Simpulan}

Produk yang dihasilkan dalam penelitian dan pengembangan ini adalah media pembelajaran menulis teks cerpen berbasis multimedia interaktif untuk siswa SMA. Media yang dihasilkan dikemas secara praktis dalam CD. Media memiliki enam menu utama, yaitu kompetensi, materi, latihan, evaluasi, sumber belajar, dan profil pengembang. Berdasarkan hasil validasi yang telah dilakukan diperoleh data yang menunjukkan bahwa media telah layak dan dapat diimplementasikan dalam pembelajaran di sekolah. Media pembelajaran yang dihasilkan memiliki tampilan yang menarik sehingga dapat menumbuhkan motivasi belajar siswa. Kemenarikan tersebut terlihat pada pengorganisasian isi media dan penggunaan komposisi warna-warna yang harmonis. Media pembelajaran ini juga menggunakan bahasa yang komunikatif dan interaktif sehingga mudah dipahami dan siswa dapat berinteraksi langsung dengan media. Penggunaan tombol-tombol interaktif yang konsisten juga dapat memudahkan siswa dalam mengoperasikan media. Media juga diiringi dengan instrumen musik yang dapat membuat suasana belajar jadi santai dan menyenangkan. Dengan demikian, berdasarkan hasil uji validasi produk dapat disimpulkan 
ISSN : 23557083

Volume 4 Nomor 1 Juni 2017

bahwa media telah layak untuk diimplementasikan dalam pembelajaran di sekolah.

\section{Saran}

Saran diberikan dalam tiga bagian, yaitu saran pemanfaatan, diseminasi, dan pengembangan selanjutnya. Pertama, saran pemanfaatan dalam pembelajaran, guru sebagai fasilitator hendaknya dapat memberikan informasi terlebih dahulu kepada siswa tentang media pembelajaran. Hal ini dianggap perlu karena adanya kemungkinan terdapat beberapa siswa yang belum paham terhadap media yang digunakan. Media pembelajaran menulis teks cerpen ini juga dapat dimanfaatkan oleh siswa dalam membantu dan melatih untuk mengembangkan kemampuannya dalam menulis teks cerpen. Kedua, saran dideminasi produk dapat dilakukan dengan cara melakukan sosialisasi pada sekolah-sekolah untuk mengenalkan media pembelajaran. Selain itu, diseminasi juga dapat dilakukan dengan cara sosialisasi pada forum MGMP serta dipasarkan secara online melalui internet. Ketiga, untuk pengembangan lebih lanjut, peneliti lain dapat mengembangkan media pembelajaran yang lebih kreatif dan inovatif lagi, serta hendaknya melakukan uji keefektifan produk dan melakukan uji coba pada kelompok yang lebih luas.

\section{DAFTAR PUSTAKA}

Ariani, N. \& Haryanto, D. 2010. Pembelajaran Multimedia di Sekolah: Pedoman Pembelajaran Inspiratif, Konstruktif, dan Prospektif. Jakarta: Prestasi Pustaka.

Arifin, Z. \& Setiyawan, A. 2012. Pengembangan Pembelajaran Aktif dengan ICT. Yogyakarta: Skripta Media Creative.

Arsyad, A. 2009. Media Pembelajaran. Jakarta: Raja Grafindo Persada.

Borg, W.R. \& Gall, M.D. 1983. Educational Reasearch: An Introduction. New York: Longman.

Darliana. 1991. Pendekatan SPIKK (Pengajaran yang Mengaktifkan Siswa Berpikir Kritis dan Kreatif. Bandung: PPPG IPA. 
Darmawan, D. 2011. Teknologi Pembelajaran. Bandung: Remaja Rosdakarya.

Kuncoro, M. 2009. Mahir Menulis: Kiat Jitu Menulis Artikel, Opini, Kolom, dan Resensi Buku. Jakarta: Erlangga.

Martutik. \& Rani, A. 2012. Menulis Dasar Berbasis Tugas. Malang: Surya Pena Gemilang.

Mas'ud, M. 2012. Membuat Multimedia dengan Lectora. Yogyakarta: Pustaka Shonif.

Mbulu, J. \& Suhartono. 2004. Pengembangan Bahan Ajar. Malang: Laboratorium Teknologi Pendidikan Fakultas Ilmu Pendidikan Universitas Negeri Malang.

Muslich, M. 2010. Text Book Writing: Dasar-Dasar Pemahaman, Penulisan, dan Pemakaian Buku Tulisan. Yogyakarta: Ar-Ruz Media.

Nasinha, I. 2012. Pengembangan Media Pembelajaran Menulis Puisi Berbasis Tayangan Acara Televisi untuk Siswa Kelas VIII. Skripsi tidak diterbitkan. Malang: Fakultas Sastra Universitas Negeri Malang.

Pribadi, B. \& Katrin, Y. 2004. Media Teknologi. Jakarta: Universitas Terbuka.

Priyatni, Endah. 2013. Landasan Pembelajaran Bahasa Indonesia. Malang: Universitas Negeri Malang.

Sadiman, A. 2008. Media Pendidikan: Pengertian, Pengembangan, dan Pemanfaatannya. Jakarta: Grafindo Pers.

Siswanto, W. 2014. Cara Menulis Cerita. Malang: Aditya Media Publishing.

Soeparno, Paul.1997. Filsafat Kontruktivisme dalam Pendidikan. Yogyakarta: Kanisius Sudjana, N. \& Rivai, A. 2010. Media Pengajaran. Bandung: Sinar Baru Algensindo.

Sugihastuti. 2009. Editor Bahasa. Yogyakarta: Pustaka Belajar.

Suprijono, Agus. 2011. Cooperative Learning. Yogyakarta: Pustaka Pelajar 